\title{
ИЗМЕНЕНИЕ АГРОФИЗИЧЕСКИХ СВОЙСТВ ЧЕРНОЗЕМА ВЫЩЕЛОЧЕННОГО В ЗАВИСИМОСТИ ОТ ПРИМЕНЕНИЯ МЕСТНЫХ КРЕМНИЙСОДЕРЖАЩИХ ПОРОД И УДОБРЕНИЙ
}

\author{
Н. П. Чекаев, канд. с.-х. наук, доцент; А. Е. Рябов, аспирант; \\ Т. А. Власова, канд. с.-х. наук, доцент; Ю. В. Корягин, канд. с.-х. наук, доцент \\ Федеральное государственное бюджетное образовательное учреждение \\ высшего образования «Пензенский государственный аграрный университет», Россия, \\ т. 8(8412) 62-83-67, e-mail: chekaev1975@mail.ru
}

В статье приведены результаты исследований по изучению влияния кремнийсодержащей породы (диатомита) и удобрений на агрофизические свойства чернозема выщелоченного и урожайность сельскохозяйственных культур. Как показали исследования, проведенные в 2015-2017 гг. в учебно-производственном центре ФГБОУ ВО Пензенский ГАУ (Пензенская область, Мокшанский район), за три года действия норм диатомита от 2 до 8 т/га количество водопрочных агрегатов на вариантах без удобрений изменялось незначительно, разница с исходными значениями составила от 1,1 до 2,6 \%. На фоне применения навоза с внесением разных норм диатомита наблюдали увеличение количества водопрочных агрегатов по сравнению с исходным значением на $13,6 \%$ на варианте без диатомита и на $20,9 \%$ на варианте с нормой диатомита 8 т/га. На фоне применения минеральных удобрений разница составила от 1,8 до 4,7 \%. Улучшая структурное состояние и оказывая разуплотняющее влияние на пахотный горизонт, применение диатомита и органических удобрений повышает урожайность сельскохозяйственных культур. Дозы диатомита от 2,0 до 8,0 т/га увеличивали урожайность культур на $8,9-18,4 \%$. На фоне применения навоза в норме 48 т/га повышается урожайность первой культуры - озимой пшеницы на 69,8-86,3 \%, урожайность второй и третьей культуры от 13,7 до 26,5 \%.

Ключевые слова: кремнийсодержащая порода, навоз, минеральные удобрения, водопрочность почвенных агрегатов, плотность сложения, пористость, урожайность.

\section{Введение}

Антропогенные изменения почвенных свойств охватывают практически все известные характеристики и качества почв, начиная от уровня содержания доступных форм питательных элементов до морфогенетического строения почвенного профиля, их гидрологического и геохимического режимов. Они могут иметь самую различную направленность, интенсивность, пространственно-временные рамки и предельный потенциал своего развития, которые определяются как характером антропогенных воздействий, так и провинциально-генетическими особенностями почв [5, 12, 13].

Сильное обесструктуривание и переуплотнение верхних горизонтов пахотных почв нарушает их гидрофизические функции, способность запасать и экономно расходовать значительные объемы продуктивной влаги для растений. Возрастает поверхностный сток и смыв. Результатом являются ускоренная эрозия и агрогенное иссушение пахотных почв. Одновременно качественно ухудшаются основные агрофизические и технологические функции почв, возрастает сопротивление при обработке, затрудняется работа уборочной техники, увеличиваются удельные затраты топлива и износ машин [5, 11, 12].

С возрастом пашни постепенно развивается комплексное явление выпахивания почв, которое включает в себя сложные сочетания деградационных процессов: ухудшение водно-воздушного режима вследствие утраты почвой структуры и уплотнения, ухудшение систем обработки вследствие ухудшения фризико-механических свойств пахотного слоя $[12,13]$.

Выбор приемов для поддержания и оптимизации почвенного плодородия должен быть сопряжен с конкретными почвенноклиматическими условиями и с экологическими ограничениями, учетом их энергоемкости и экономической эффективности [5].

Исследования, проведенные с применением природных диатомитов, расширили возможности применения кремния и его соединений в сельском хозяйстве $[1,3,7$, $10,16,17,19]$. В настоящее время механизм действия кремнийсодержащих пород в почвенных процессах еще недостаточно изучен [2, 4, 6, 8, 18]. 
В России запасы кремнийсодержащих агроруд (диатомитов) встречаются в Ульяновской и Пензенской областях, а также на Урале и в Сибири [2, 9, 15, 18]. На территории Пензенской области выявлены три месторождения диатомитов (Ахматовское, Холеневское и Коржевское) с запасами сырья соответственно $3,5,2,8$ и 5,5 млн. м ${ }^{3}$. В этом свете становится особенно интересной перспектива использования местных кремнийсодержащих пород, добываемых в Пензенской области (Никольский район, Коржевское месторождение), для воспроизводства плодородия почв и повышения продуктивности сельскохозяйственных культур $[11,13,14]$.

\section{Методы и материалы}

Исследования с целью изучения влияния местных кремнийсодержащих пород на свойства чернозема выщелоченного и урожайность сельскохозяйственных культур проводились в 2014-2017 гг. на опытном поле учебно-производственного центра ФГБОУ ВО Пензенский ГАУ (Пензенская область, Мокшанский район) по следующей схеме:

Фактор A - нормы кремнийсодержащей породы (диатомита): 1. Без диатомита (кон- троль); 2. Диатомит 2 т/га; 3. Диатомит 4 т/га; 4. Диатомит 6 т/га; 5. Диатомит 8 т/га.

Фактор В - нормы внесения органических и минеральных удобрений: 1. Без удобрений (контроль); 2. Навоз 48 т/га; 3. $\mathrm{N}_{80} \mathrm{P}_{40} \mathrm{~K}_{96}$ ежегодно (эквивалентно 16 т/га навоза). Размещение вариантов опыта - методом рендомизированных повторений. Повторность четырехкратная. Общая площадь делянки $36 \mathrm{~m}^{2}$. Учетная площадь $25 \mathrm{~m}^{2}$.

Почва опытного участка - чернозем выщелоченный среднегумусный среднемощный тяжелосуглинистый. Исследования проводились на опытном участке с чередованием культур: озимая пшеница (2015г.), яровая пшеница (2016 г.), горох (2017 г.).

Диатомит характеризовался следующим составом: $\mathrm{SiO}_{2}-78,8 \% ; \mathrm{A1}_{2} \mathrm{O}_{3}-$ $6,9 \% ; \mathrm{Fe}_{2} \mathrm{O}_{3}-3,8 \% ; \mathrm{TiO}_{2}-0,48 \% ; \mathrm{CaO}-$ $0,39 \% ; \mathrm{MgO}-0,89 \% ; \mathrm{SO}_{3}-0,27 \% ; \mathrm{Na}_{2} \mathrm{O}-$ $0,30 \% ; \mathrm{K}_{2} \mathrm{O}-1,8 \% ; \mathrm{P}_{2} \mathrm{O}_{5}-0,04 \%$.

\section{Результаты}

Многие важнейшие с агрономической точки зрения водно-фризические свойства почвы - водопроницаемость, плотность, пористость, влагоемкость и другие - находятся в функциональной связи с агрегатным составом почвы.

Таблица 1

Влияние диатомита, навоза и минеральных удобрений на водопрочность макроагрегатов в черноземе выщелоченном

\begin{tabular}{|c|c|c|c|c|c|c|}
\hline \multirow{2}{*}{ Вариант опыта } & \multicolumn{6}{|c|}{ Норма внесения органических и минеральных удобрений (фактор В) } \\
\hline & \multicolumn{2}{|c|}{ Без удобрений } & \multicolumn{2}{|c|}{ Навоз 48 т/га } & \multicolumn{2}{|c|}{$\mathrm{N}_{80} \mathrm{P}_{40} \mathrm{~K}_{96}$} \\
\hline $\begin{array}{c}\text { Норма диатомита } \\
\text { (фрактор A) }\end{array}$ & \begin{tabular}{|c|} 
Количество \\
водопрочных \\
макроагре- \\
гатов, \% \\
\end{tabular} & $\begin{array}{c}\text { Коэфффиц } \\
\text { иент } \\
\text { структур- } \\
\text { ности } \\
\end{array}$ & \begin{tabular}{|c|} 
Количество \\
водопрочных \\
макроагре- \\
гатов, \% \\
\end{tabular} & \begin{tabular}{|c|} 
Коэфффи- \\
циент \\
структур- \\
ности \\
\end{tabular} & \begin{tabular}{|c|} 
Количество \\
водопрочных \\
макроагре- \\
гатов, \% \\
\end{tabular} & \begin{tabular}{|c} 
Коэфффи- \\
циент \\
структур- \\
ности
\end{tabular} \\
\hline \multicolumn{7}{|c|}{2015 г. } \\
\hline 1. Без диатомита & $52,2^{*}$ & $1,09^{*}$ & 56,8 & 1,31 & 51,7 & 1,07 \\
\hline 2. Диатомит 2 т/га & 52,4 & 1,10 & 60,5 & 1,53 & 52,2 & 1,09 \\
\hline 3. Диатомит 4 т/га & 55,8 & 1,26 & 62,0 & 1,63 & 56,1 & 1,28 \\
\hline 4. Диатомит 6 т/га & 56,0 & 1,27 & 64,2 & 1,79 & 57,5 & 1,35 \\
\hline 5. Диатомит 8 т/га & 58,1 & 1,39 & 65,6 & 1,91 & 60,1 & 1,51 \\
\hline \multirow{2}{*}{\multicolumn{7}{|c|}{ НСР 05 : Фактор А - 2,4; Фактор В - 1,8; Варианты (A+В) - 3,2 }} \\
\hline & & & & & & \\
\hline 1. Без диатомита & $51,7^{*}$ & $1,07^{*}$ & 67,5 & 2,07 & 50,2 & 1,01 \\
\hline 2. Диатомит 2 т/га & 51,9 & 1,08 & 71,2 & 2,47 & 50,7 & 1,03 \\
\hline 3. Диатомит 4 т/га & 54,2 & 1,18 & 72,7 & 2,67 & 54,5 & 1,20 \\
\hline 4. Диатомит 6 т/га & 53,8 & 1,17 & 74,9 & 2,99 & 55,8 & 1,26 \\
\hline 5. Диатомит 8 т/га & 55,9 & 1,27 & 76,4 & 3,23 & 58,3 & 1,40 \\
\hline \multicolumn{7}{|c|}{ HCP $_{05}$ : Фактор А - 1,9; Фактор В - 2,1; Варианты (А+В) - 2,6 } \\
\hline \multicolumn{7}{|l|}{2017 г. } \\
\hline 1. Без диатомита & $50,9^{*}$ & $1,04^{*}$ & 65,8 & 1,93 & 49,9 & 1,00 \\
\hline 2. Диатомит 2 т/га & 51,1 & 1,05 & 69,5 & 2,27 & 50,4 & 1,02 \\
\hline 3. Диатомит 4 т/га & 53,9 & 1,17 & 70,9 & 2,44 & 54,2 & 1,18 \\
\hline 4. Диатомит 6 т/га & 53,8 & 1,17 & 73,1 & 2,72 & 55,6 & 1,25 \\
\hline 5. Диатомит 8 т/га & 54,8 & 1,21 & 73,1 & 2,71 & 56,9 & 1,32 \\
\hline \multicolumn{7}{|c|}{ HCP $_{05}$ : Фактор A - 1,2; Фактор В - 1,8; Варианты (A+B) - 2,6 } \\
\hline
\end{tabular}


Исследования показали, что уже в первый год действия (2015 г.) содержание водопрочных макроагрегатов в черноземе выщелоченном зависит от применяемых удобрений и доз диатомита (табл. 1). Максимальное количество водопрочных макроагрегатов наблюдали на вариантах с внесением разных доз диатомита на фоне навоза. Содержание водопрочных агрегатов на этих вариантах было 60,5-65,6 \%, что на 8,3-13,4 \% было выше, чем на контрольном варианте. Разные дозы диатомита увеличивали водопрочность макроагрегатов на 0,2-5,9\%. Навоз в дозе 48 т/га увеличивал содержание водопрочных агрегатов на 4,6 \%, а на варианте с внесением минеральных удобрений без диатомита наблюдали снижение количества агрегатов на $0,5 \%$, что является несущественным изменением.

В 2015 году коэффрициент структурности на варианте без удобрений и диатомита составлял 1,09, при использовании разных доз диатомита - 1,10-1,39, а при использовании навоза коэффицциент структурности изменялся от 2,01 до 3,10.

На второй год действия (2016 г.) в вариантах с внесением разных доз диатомита без удобрений наблюдали снижение количества водопрочных агрегатов. На фоне без удобрений количество водопрочных агрегатов колебалось от 51,7 до 55,9 \%. На фоне применения навоза 48 т/га количество водопрочных агрегатов увеличилось и составило в зависимости от норм диатомита от 71,2 до 76,4 \%. На фоне применения минеральных удобрений количество водопрочных агрегатов уменьшилось и составило от 50,2 \% на варианте без диатомита до $58,3 \%$ на варианте с диатомитом в норме 8 т/га.

В 2017 году на всех вариантах наблюдали снижение количества водопрочных макроагрегатов. На фоне без удобрений их количество составило от 50,9 \% на варианте без диатомита до 54,8 \% на варианте с нормой диатомита 8 т/га. Коэффициент структурности на вариантах с разными нормами диатомита на фоне без удобрений составил от 1,05 до 1,21, а на фоне навоза от 2,27 до 2,72.

За 3 года действия норм диатомита от 2 до 8 т/га количество водопрочных агрегатов на вариантах без удобрений изменялось незначительно, разница с исходными значениями составила от 1,1 до $2,6 \%$. На фоне применения навоза с внесением разных норм диатомита наблюдали увеличение количества водопрочных агрегатов по сравнению с исходным значением на $13,6 \%$ на варианте без диатомита и на 20,9\% на варианте с нормой диатомита 8 т/га. На

Таблица 2

Влияние диатомита, навоза и минеральных удобрений на плотность сложения

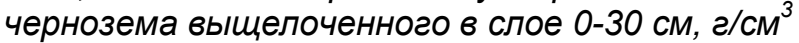

\begin{tabular}{|c|c|c|c|c|c|c|}
\hline \multirow{2}{*}{ Вариант опыта } & \multicolumn{6}{|c|}{ Норма внесения органических и минеральных удобрений (фактор В) } \\
\hline & \multicolumn{2}{|c|}{ Без удобрений } & \multicolumn{2}{|c|}{ Навоз 48 т/га } & \multicolumn{2}{|c|}{$\mathrm{N}_{80} \mathrm{P}_{40} \mathrm{~K}_{96}$} \\
\hline $\begin{array}{c}\text { Норма диатомита } \\
\text { (фрактор A) }\end{array}$ & $\begin{array}{c}\text { Плотность } \\
\text { сложения } \\
\text { в начале } \\
\text { вегетации }\end{array}$ & $\begin{array}{c}\text { Плотность } \\
\text { сложения } \\
\text { в конце } \\
\text { вегетации }\end{array}$ & $\begin{array}{c}\text { Плотность } \\
\text { сложения } \\
\text { в начале } \\
\text { вегетации }\end{array}$ & $\begin{array}{c}\text { Плотность } \\
\text { сложения } \\
\text { в конце } \\
\text { вегетации }\end{array}$ & $\begin{array}{c}\text { Плотность } \\
\text { сложения } \\
\text { в начале } \\
\text { вегетации }\end{array}$ & $\begin{array}{c}\text { Плотность } \\
\text { сложения } \\
\text { в конце } \\
\text { вегетации }\end{array}$ \\
\hline \multicolumn{7}{|c|}{2015 г. } \\
\hline 1. Без диатомита & $1,11^{*}$ & $1,27^{*}$ & 1,10 & 1,18 & 1,12 & 1,21 \\
\hline 2. Диатомит 2 т/га & 1,12 & 1,21 & 1,10 & 1,17 & 1,13 & 1,22 \\
\hline 3. Диатомит 4 т/га & 1,08 & 1,17 & 1,07 & 1,14 & 1,09 & 1,18 \\
\hline 4. Диатомит 6 т/га & 1,06 & 1,14 & 1,05 & 1,12 & 1,07 & 1,16 \\
\hline 5. Диатомит 8 т/га & 1,09 & 1,18 & 1,08 & 1,15 & 1,10 & 1,19 \\
\hline \multicolumn{7}{|c|}{2016 г. } \\
\hline 1. Без диатомита & $1,10^{*}$ & $1,25^{*}$ & 1,09 & 1,21 & 1,11 & 1,26 \\
\hline 2. Диатомит 2 т/га & 1,11 & 1,26 & 1,09 & 1,21 & 1,12 & 1,27 \\
\hline 3. Диатомит 4 т/га & 1,07 & 1,21 & 1,06 & 1,18 & 1,08 & 1,23 \\
\hline 4. Диатомит 6 т/га & 1,05 & 1,19 & 1,04 & 1,17 & 1,06 & 1,20 \\
\hline 5. Диатомит 8 т/га & 1,08 & 1,19 & 1,07 & 1,14 & 1,09 & 1,20 \\
\hline \multicolumn{7}{|c|}{2017 г. } \\
\hline 1. Без диатомита & $1,08^{*}$ & $1,26^{*}$ & 1,11 & 1,24 & 1,12 & 1,27 \\
\hline 2. Диатомит 2 т/га & 1,09 & 1,27 & 1,11 & 1,23 & 1,13 & 1,27 \\
\hline 3. Диатомит 4 т/га & 1,05 & 1,23 & 1,08 & 1,20 & 1,09 & 1,24 \\
\hline 4. Диатомит 6 т/га & 1,04 & 1,21 & 1,09 & 1,19 & 1,09 & 1,21 \\
\hline 5. Диатомит 8 т/га & 1,06 & 1,20 & 1,09 & 1,17 & 1,08 & 1,25 \\
\hline \multicolumn{7}{|c|}{ * Контрольный вариант } \\
\hline
\end{tabular}


фоне применения минеральных удобрений разница составила от 1,8 до 4,7\%.

Использование разных доз диатомита на фоне навоза и минеральных удобрений оказывают определенное влияние на величину плотности чернозема выщелоченного (табл. 2).

В конце вегетационного периода в 2015 году величина равновесной плотности на

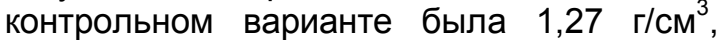
т. е. была выше оптимальной. Отклонение равновесной плотности от оптимальной

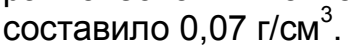

Так, при внесении разных доз диатомита в чистом виде равновесная плотность почвы в 2015 году снизилась по сравнению с контрольным вариантом на 0,06-0,13 г/см ${ }^{3}$. Под действием навоза в чистом виде величина равновесной плотности снизилась по сравнению с контрольным вариан-

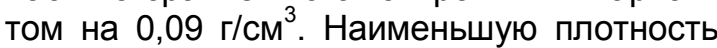
наблюдали на варианте с внесением диатомита в норме 8 т/га и навоза, плотность

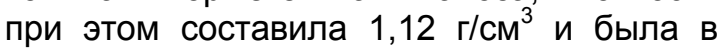
пределах оптимальной.

Применение минеральных удобрений на фоне внесения разных доз диатомита позволило снизить равновесную плотность по сравнению с контрольным вариантом на

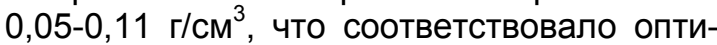
мальному пределу.

На второй год действия удобрений равновесная плотность на вариантах опыта колебалась в интервале от 1,14 до 1,26 г/см ${ }^{3}$. В зависимости от применения разных норм диатомита плотность снижалась по сравнению с контрольным вариантом на

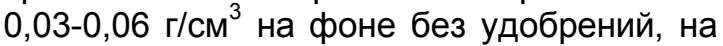
0,03-0,09 на фоне навоза 48 т/га и на 0,020,05 г/см ${ }^{3}$ на фоне применения минеральных удобрений.

На третий год действия удобрений плотность сложения почвы в конце вегетации гороха на вариантах опыта составляла

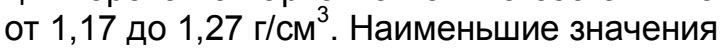
наблюдали на вариантах разных норм диатомита по фону навоза. Изменения по сравнению с контрольным вариантом составили 0,03-0,09 г/см³ и были самыми низкими на вариантах с внесением диатомита с нормами от 4 до 8 т/га. Как показали исследования, с увеличением норм диатомита от 2 до 8 т/га равновесная плотность снижалась.

Улучшая структурное состояние, диатомит и органические удобрения положительно влияли на общую пористость чернозема выщелоченного. Положительное действие в данном случае вызвано внесением навоза, а также характером погодных условий, сложившихся в течение вегетации.

В наших опытах величина общей пористости в конце вегетационного периода

Таблица 3

Влияние диатомита, навоза и минеральных удобрений

на пористость чернозема выщелоченного в слое 0-30 см

\begin{tabular}{|c|c|c|c|c|c|c|}
\hline \multirow{2}{*}{ Вариант опыта } & \multicolumn{6}{|c|}{ Норма внесения органических и минеральных удобрений (фактор В) } \\
\hline & \multicolumn{2}{|c|}{ Без удобрений } & \multicolumn{2}{|c|}{ Навоз 48 т/га } & \multicolumn{2}{|c|}{$\mathrm{N}_{80} \mathrm{P}_{40} \mathrm{~K}_{96}$} \\
\hline $\begin{array}{c}\text { Норма диатомита } \\
\text { (фактор A) }\end{array}$ & \begin{tabular}{|l|} 
Пористость \\
в начале ве- \\
гетации, \%
\end{tabular} & $\begin{array}{l}\text { Пористость } \\
\text { в конце ве- } \\
\text { гетации, \% }\end{array}$ & $\begin{array}{l}\text { Пористость } \\
\text { в начале ве- } \\
\text { гетации, \% }\end{array}$ & $\begin{array}{l}\text { Пористость } \\
\text { в конце ве- } \\
\text { гетации, \% }\end{array}$ & \begin{tabular}{|l|} 
Пористость \\
в начале ве-- \\
гетации, \%
\end{tabular} & $\begin{array}{l}\text { Пористость } \\
\text { в конце ве- } \\
\text { гетации, \% }\end{array}$ \\
\hline \multicolumn{7}{|c|}{2015 г. } \\
\hline 1. Без диатомита & $53,4^{*}$ & $49,6^{*}$ & 53,8 & 50,6 & 52,9 & 49,1 \\
\hline 2. Диатомит 2 т/га & 52,9 & 49,2 & 53,9 & 50,6 & 52,5 & 48,7 \\
\hline 3. Диатомит 4 т/га & 54,6 & 51,0 & 55,1 & 51,9 & 54,2 & 50,5 \\
\hline 4. Диатомит 6 т/га & 55,5 & 51,9 & 55,9 & 52,8 & 55,0 & 51,4 \\
\hline 5. Диатомит 8 т/га & 54,2 & 50,5 & 54,7 & 51,5 & 53,7 & 50,0 \\
\hline \multicolumn{7}{|c|}{2016 г. } \\
\hline 1. Без диатомита & $53,8^{*}$ & $47,6^{*}$ & 54,3 & 49,1 & 53,4 & 47,1 \\
\hline 2. Диатомит 2 т/га & 53,4 & 47,1 & 54,3 & 49,2 & 53,0 & 46,6 \\
\hline 3. Диатомит 4 т/га & 55,1 & 49,0 & 55,5 & 50,5 & 54,6 & 48,5 \\
\hline 4. Диатомит 6 т/га & 55,9 & 50,0 & 56,3 & 50,9 & 55,5 & 49,5 \\
\hline 5. Диатомит 8 т/га & 54,7 & 50,0 & 55,1 & 52,0 & 54,2 & 49,5 \\
\hline \multicolumn{7}{|c|}{2017 г. } \\
\hline 1. Без диатомита & $54,0^{*}$ & $48,1^{*}$ & 53,8 & 49,3 & 53,1 & 47,6 \\
\hline 2. Диатомит 2 т/га & 53,6 & 47,6 & 53,9 & 49,3 & 52,6 & 47,3 \\
\hline 3. Диатомит 4 т/га & 55,2 & 49,5 & 55,1 & 50,6 & 54,3 & 49,0 \\
\hline 4. Диатомит 6 т/га & 55,9 & 50,3 & 55,5 & 51,2 & 54,9 & 50,0 \\
\hline 5. Диатомит 8 т/га & 54,8 & 50,0 & 54,7 & 51,5 & 54,2 & 49,1 \\
\hline
\end{tabular}


Влияние диатомита, навоза и минеральных удобрений на пористость аэрации чернозема выщелоченного в слое 0-30 см

\begin{tabular}{|c|c|c|c|c|c|c|}
\hline \multirow[t]{2}{*}{ Вариант опыта } & \multicolumn{6}{|c|}{ Норма внесения органических и минеральных удобрений (фактор В) } \\
\hline & \multicolumn{2}{|c|}{ Без удобрений } & \multicolumn{2}{|c|}{ Навоз 48 т/га } & \multicolumn{2}{|c|}{$\mathrm{N}_{80} \mathrm{P}_{40} \mathrm{~K}_{96}$} \\
\hline $\begin{array}{c}\text { Норма диатомита } \\
\text { (фрактор A) }\end{array}$ & $\begin{array}{l}\text { Пористость } \\
\text { аэрации в } \\
\text { начале ве- } \\
\text { гетации, \% }\end{array}$ & $\begin{array}{c}\text { Пористость } \\
\text { аэрации в } \\
\text { конце веге- } \\
\text { тации, \% }\end{array}$ & \begin{tabular}{|} 
Пористость \\
аэрации в \\
начале ве- \\
гетации, \%
\end{tabular} & $\begin{array}{c}\text { Пористость } \\
\text { аэрации в } \\
\text { конце веге- } \\
\text { тации, \% }\end{array}$ & $\begin{array}{c}\text { Пористость } \\
\text { аэрации в } \\
\text { начале ве- } \\
\text { гетации, \% }\end{array}$ & $\begin{array}{c}\text { Пористость } \\
\text { аэрации в } \\
\text { конце веге- } \\
\text { тации, \% }\end{array}$ \\
\hline \multicolumn{7}{|c|}{2015 г. } \\
\hline 1. Без диатомита & $24,1^{*}$ & $24,0^{*}$ & 23,7 & 24,2 & 23,3 & 23,2 \\
\hline 2. Диатомит 2 т/га & 23,4 & 23,3 & 23,8 & 24,3 & 22,6 & 22,5 \\
\hline 3. Диатомит 4 т/га & 26,1 & 26,0 & 25,8 & 26,3 & 25,4 & 25,3 \\
\hline 4. Диатомит 6 т/га & 27,5 & 27,4 & 27,1 & 27,7 & 26,8 & 26,7 \\
\hline 5. Диатомит 8 т/га & 25,4 & 25,3 & 25,1 & 25,6 & 24,7 & 24,6 \\
\hline \multicolumn{7}{|c|}{2016 г. } \\
\hline 1. Без диатомита & $24,8^{*}$ & $20,9^{*}$ & 24,5 & 22,0 & 24,1 & 20,2 \\
\hline 2. Диатомит 2 т/га & 24,1 & 20,2 & 24,5 & 22,0 & 23,4 & 19,4 \\
\hline 3. Диатомит 4 т/га & 26,8 & 23,1 & 26,5 & 24,1 & 26,1 & 22,3 \\
\hline 4. Диатомит 6 т/га & 28,2 & 24,5 & 27,9 & 24,8 & 27,5 & 23,7 \\
\hline 5. Диатомит 8 т/га & 26,2 & 24,6 & 25,8 & 26,4 & 25,4 & 23,9 \\
\hline \multicolumn{7}{|c|}{2017 г. } \\
\hline 1. Без диатомита & $26,3^{*}$ & $20,1^{*}$ & 23,0 & 20,4 & 23,3 & 19,5 \\
\hline 2. Диатомит 2 т/га & 25,6 & 19,4 & 23,0 & 20,5 & 22,6 & 19,5 \\
\hline 3. Диатомит 4 т/га & 28,3 & 22,3 & 25,0 & 22,6 & 25,4 & 21,6 \\
\hline 4. Диатомит 6 т/га & 28,9 & 23,0 & 24,3 & 23,3 & 25,3 & 23,1 \\
\hline 5. Диатомит 8 т/га & 27,6 & 23,8 & 24,3 & 24,9 & 26,2 & 20,9 \\
\hline
\end{tabular}

2015 года на всех вариантах опыта была в пределах оптимальной и изменялась от 48,7 до $52,8 \%$ (табл. 3 ).

На вариантах с использованием разных доз диатомита на фоне навоза величина общей пористости колебалась в пределах 50,6-52,8 \%, превышая значения этого показателя на контрольном варианте на $1,0-3,2 \%$.

В 2016 году пористость почвы в конце вегетационного периода на вариантах опыта колебалась от 47,1 до $52,0 \%$. На фоне без удобрений разные нормы диатомита увеличивали пористость почвы на 1,4$2,4 \%$, и она была самой высокой на вариантах с внесением диатомита 6 и 8 т/га.

На вариантах с применением навоза 48 т/га пористость почвы изменялась в пределах от 49,1 до 52,0 \% и была самой высокой на варианте с применением 8 т/га диатомита. Увеличение по сравнению с контрольным вариантом составило 1,5$4,4 \%$.

На фроне применения эквивалентных доз минеральных удобрений пористость почвы была в пределах 47,1-49,5\%. Применение разных норм диатомита увеличило пористость почвы на 1,4-2,4\%, и она была наибольшей на варианте с применением 8 т/га диатомита.
В 2017 году на вариантах опыта пористость почвы в конце вегетационного периода была на уровне $47,3-51,5 \%$. Наибольшие значения общей пористости были на фоне применения навоза. Увеличения по сравнению с контрольным вариантом составили 1,2-3,1\%.

Пористость аэрации в конце вегетационного периода 2015 года на вариантах опыта изменялась в интервале от 22,5$27,7 \%$ и была в пределах оптимальной (табл. 4).

На контрольном варианте значения этого показателя в течение вегетации были на уровне 24,0-24,1\%, что связано, в первую очередь, с погодными условиями и влажностью почвы в момент проведения анализов.

В зависимости от норм диатомита величина пористости аэрации изменялась на фоне без удобрений в пределах 23,3-27,4 \%, на фоне навоза 24,3-27,7\%, а на фоне минеральных удобрений 22,5-26,7 \%.

В 2016 году в конце вегетационного периода наблюдали аналогичную картину. Самые высокие значения пористости аэрации наблюдали на вариантах с внесением навоза в норме 48 т/га. Значения пористости аэрации на этом фоне колебались от 22,0 до 26,4 \% и повышались с увеличени- 
Урожайность сельскохозяйственных культур в зависимости от применения диатомита и удобрений

\begin{tabular}{|c|c|c|c|}
\hline \multirow[t]{2}{*}{ Вариант опыта } & \multicolumn{3}{|c|}{ Урожайность культур, т/га } \\
\hline & $\begin{array}{c}2015 \text { г. - } \\
\text { озимая пшеница }\end{array}$ & $\begin{array}{c}2016 \text { г. - } \\
\text { яровая пшеница }\end{array}$ & $\begin{array}{l}2017 \text { г. - } \\
\text { горох }\end{array}$ \\
\hline \multicolumn{4}{|c|}{ Фон 1 - без удобрений } \\
\hline 1. Без диатомита & 2,02 & 2,22 & 1,88 \\
\hline 2. Диатомит 2 т/га & 2,24 & 2,46 & 2,09 \\
\hline 3. Диатомит 4 т/га & 2,33 & 2,56 & 2,14 \\
\hline 4. Диатомит 6 т/га & 2,40 & 2,64 & 2,17 \\
\hline 5. Диатомит 8 т/га & 2,47 & 2,72 & 2,20 \\
\hline \multicolumn{4}{|c|}{ Фон 2 - навоз 16 т/га севооборотной пашни } \\
\hline 1. Без диатомита & 3,43 & 2,45 & 2,18 \\
\hline 2. Диатомит 2 т/га & 3,66 & 2,61 & 2,25 \\
\hline 3. Диатомит 4 т/га & 3,96 & 2,83 & 2,40 \\
\hline 4. Диатомит 6 т/га & 4,09 & 2,92 & 2,44 \\
\hline 5. Диатомит 8 т/га & 3,98 & 2,84 & 2,41 \\
\hline \multicolumn{4}{|c|}{ Фон 3 - NPK эквивалентно 16 т/га навоза ежегодно } \\
\hline 1. Без диатомита & 3,30 & 2,75 & 2,63 \\
\hline 2. Диатомит 2 т/га & 3,47 & 2,89 & 2,66 \\
\hline 3. Диатомит 4 т/га & 3,60 & 3,00 & 2,78 \\
\hline 4. Диатомит 6 т/га & 3,47 & 2,89 & 2,73 \\
\hline 5. Диатомит 8 т/га & 3,66 & 3,05 & 2,86 \\
\hline $\mathrm{HCP}_{05}$ & & & \\
\hline Фактор A & 0,22 & 0,23 & 0,17 \\
\hline Фактор В & 0,28 & 0,25 & 0,18 \\
\hline Варианты (A+B) & 0,31 & 0,34 & 0,21 \\
\hline
\end{tabular}

ем норм диатомита. Разница с контрольным вариантом составляла 1,1-5,5\%. В 2017 году пористость аэрации в конце вегетационного периода составляла на опытах в пределах 19,5-24,9\%. На фооне без удобрений разные дозы диатомита увеличивали значения пористости аэрации на 2,2-3,7\%, на фооне навоза на 0,1-4,5\%, а на фоне минеральных удобрений на 2,1$3,6 \%$. Значения пористости аэрации на вариантах с применением нормы диатомита 2 т/га были на уровне вариантов без применения диатомита. Увеличение значений пористости аэрации наблюдали при увеличении норм диатомита от 4 до 8 т/га.

Урожайность сельскохозяйственных культур определилась в зависимости от внесения доз диатомитсодержащей породы и удобрений. Наибольшую урожайность зерна озимой пшеницы в 2015 году наблюдали на вариантах с внесением разных норм диатомита по фону использования навоза. Прибавки урожая озимой пшеницы по сравнению с контрольным вариантом составили 1,41-2,07 т/га. Это, в основном, связано с тем, что с нормой навоза 48 т/га внесли 240 кг азота, 120 кг фосффора и 288 кг калия (табл. 5).

В 2016 году урожайность зерна яровой пшеницы на вариантах опыта составила 2,22-3,05 т/га. В зависимости от доз диато- мита прибавки урожая составили 0,24-0,5 т/га. Наибольшие прибавки были на вариантах с применением минеральных удобрений. Урожайность на вариантах с ежегодным применением минеральных удобрений с нормами $\mathrm{N}_{80} \mathrm{P}_{40} \mathrm{~K}_{96}$ составили от 2,75 до 3,05 т/га.

Урожайность гороха на третий год действия удобрений и диатомита составила от 1,88 до 2,86 т/га. Действие минеральных удобрений на урожайность гороха проявилось сильнее, чем последействие нормы навоза 48 т/га. Отклонения от контрольного варианта составили 0,75-0,98 т/га. Дозы диатомита повысили урожайность зерна гороха на 0,21-0,32 т/га.

\section{Заключение}

Применение диатомита и органических удобрений, улучшая структурное состояние и оказывая разуплотняющее влияние на пахотный горизонт, увеличивают как общую пористость, так и пористость аэрации. Наибольшее влияние на восстановление утраченной структуры и оптимизацию равновесной плотности наблюдали на варианте с совместным применением 8 т/га диатомита и навоза нормой 48 т/га. За три года действия диатомита и удобрений количество водопрочных агрегатов по сравнению с исходным значением повысилось на $20,9 \%$. 
Применение навоза в норме 48 т/га в зависимости от разных доз диатомита увеличивает урожайность первой культуры озимой пшеницы - на 69,8-86,3 \%, урожайность второй культуры - яровой пшеницы на 15,8-26,5 \%, а третьей культуры - гороха - на 13,7-22,0\%. При использовании минеральных удобрений нормой $\mathrm{N}_{80} \mathrm{P}_{40} \mathrm{~K}_{96}$ на фоне применения диатомита урожайность зерна озимой пшеницы повысилась на 63,4-66,3\%, яровой пшеницы на 27,2$30,5 \%$, гороха на 28,5-34,2 \%. Разные дозы диатомита без применения удобрений повысили урожайность озимой пшеницы на 8,9-18,2 \%, яровой пшеницы на 9,7-18,4 \%, гороха на 10,0-14,5\%.

\section{Лumepamypa}

1. Байбеков, Р. Ф. Агроэкологическое состояние почв при длительном применении удобрений / Р. Ф. Байбеков. - М.: ЦИНАО, 2003. - 192 с.

2. Голованов, Д. Л. Кремний - незаменимый макроэлемент питания природных и культурных злаков / Д. Л. Голованов // Удобрения и химические мелиоранты в агроэкосистемах. - М.: Изд-во МГУ, 1998. - С. 247-250.

3. Дабахова, Е. В. Изучение кремнийсодержащих препаратов / Е. В. Дабахова, Н. В. Забегалов // Агрохимический вестник. - 2011. - № 2. - С. 28-35.

4. Дистанов, У.Г. Геолого-промышленные типы месторождений осадочных кремнистых пород СССР: критерии их прогноза и поисков / У. Г. Дистанов // Происхождение и практическое использование кремнистых пород: Сборник статей АН СССР / отв. ред. В.Н. Холодов, И. В. Седнецкий. - Москва: Наука, 1987. - С. 157-167.

5. Использование соединений кремния в сельском хозяйстве / В. М. Дьяков, В. В. Матыченков, В. А. Чернышев, Я. М. Аммосова // Актуальные вопросы химической науки и технологии и охраны окружающей среды. Вып. 7. - Москва: НИИТЭХИМ, 1990. - 32 с.

6. Карпухин, М. Ю. Эффективность использования диатомита в качестве удобрения при возделывании моркови в условиях Среднего Урала // Аграрный вестник Урала. - 2014. - № 1 (119). - C.17-19.

7. Кремниевые удобрения как фактор повышения засухоустойчивости растений / В. В. Матыченков, А. А. Кособрюхов, Н. И. Шабанова, Е. А. Бочарникова // Агрохимия. - 2007. - № 5. - С.63-67.

8. Куликова, А. Х. Эффективность использования диатомита и его смеси с минеральными удобрениями при возделывании озимой и яровой пшеницы / А. Х. Куликова, Е. А. Яшин, Е. В. Данилова // Вестник Ульяновской ГСХА. - 2008. - № 1 (16). - С. 8-14.

9. Куликова, А. Х. Кремний и высококремнистые породы в системе удобрений сельскохозяйственных культур: монография / А. Х. Куликова. - Ульяновск: УГСХА им. П. А. Столыпина, 2013. - 178 с.

10. Куликова, А. Х. Перспективы использование диатомита в сельскохозяйственном производстве / А. Х. Куликова // Агроэкологические проблемы сельскохозяйственного производства в условиях антропогенного загрязнения: материалы Всероссийской научно-практической конференции. - Ульяновск, 2004. - С. 187-191.

11. Куликова, А. Х. Применение биопрепаратов и диатомитового порошка при возделывании ячменя / А. Х. Куликова, С. А. Никифорова, Е. А. Никифоров // Плодородие. - 2008. - № 5. C. $36-37$.

12. Лобода, Б. П. Диатомиты и трепелы как почвоулучшители и источники биогенных элементов / Б. П. Лобода, Н. Н. Яковлева // Плодородие. - 2003. - № 5. - С. 11-14.

13. Матыченков, В. В. Роль подвижных соединений кремния в растениях и системе почварастение: автореферат диссертации на соискание ученой степени доктора биологических наук: 03.00.12, 03.00.27 / Владимир Викторович Матыченков. - Пущино, 2008. - 34 с.

14. Сычёв, В.Г. Современное состояние и динамика плодородия пахотных почв России / В. Г. Сычёв, М. И. Лунёв, А. В. Павлихина // Плодородие. - 2012. - № 4. - С. 5 - 7.

15. Яшин, Е. А. Эфрфективность использования диатомита и его смесей с куриным пометом в качестве удобрения сельскохозяйственных культур на черноземе выщелоченном Среднего Поволжья: автореферат диссертации на соискание ученой степени кандидата сельскохозяйственных наук: 06.01.04 / Евгений Александрович Яшин. - Саранск, 2004. - 20 с.

16. Barzegar, A. R. The effect of addition of different amounts and types of organic materials on soil physical properties and yield of wheat / A. R. Barzegar, A. Yousefi, A. Daryashenas // Plant Soil. 2002. - № 247. - P. 295-301.

17. Chang, M. Y. Production of silicon carbide liquid fertilizer by hydrothermal carbonization processes from silicon containing agricultural waste biomass / M. Y. Chang, W. J. Huang // Eng J-Thail. 2016. - № 20. - P. 11-17.

18. The use of silicon-containing agro ores for increasing the productivity of agricultural crops / N. P. Checkaev, I. N. Semov, A. Yu. Kuznetsov, A. N. Arefyev, E. G. Rylyakin // Research Journal of Pharmaceutical, Biological and Chemical Sciences. - 2019. - № 1. - P. 114-117.

19. Diatomite releases silica during spirit filtration / J. Gómez, Gil MLA., N. de la Rosa-Fox, M. Alguacil // Food Chem. - 2014. - № 159. - P. 381-387. 


\title{
CHANGE IN THE AGROPHYSICAL PROPERTIES OF LEACHED CHERNOZEM DEPENDING ON THE APPLICATION OF LOCAL SILICEOUS ROCKS AND FERTILIZERS
}

\author{
N. P. Chekaev, Candidate of Agricultural Sciences, Associate Professor; A. E. Ryabov, \\ graduate student; T. A. Vlasova, Candidate of Agricultural Sciences, Associate Professor; \\ Yu. V. Koryagin, Candidate of Agricultural Sciences, Associate Professor
}

Federal State Budgetary Educational Institution of Higher Education Penza State Agrarian University, Russia, t. 8(8412) 62-83-67, e-mail: chekaev1975@mail.ru

The article presents the results of studies on the influence of siliceous rocks (diatomite) and fertilizers on the agrophysical properties of leached chernozem and crop yields. As shown by the studies conducted in 2015-2017 at the training and production center of the FSBEI HE Penza SAU (Mokshan district, Penza oblast), over the three years of application of diatomite at a rate from 2 to $8 \mathrm{t} /$ ha, the number of water-resistant units in the variants without fertilizers had changed slightly, the difference compared to the initial values ranged from 1.1 to $2.6 \%$. Against the background of the use of manure with the introduction of different doses of diatomite, an increase in the number of water-resistant aggregates was observed compared with the initial value by $13.6 \%$ in the variant without diatomite and by $20.9 \%$ in the variant with a diatomite at a rate of $8 \mathrm{t} / \mathrm{ha}$. Against the background of the use of mineral fertilizers, the difference was from 1.8 to $4.7 \%$. Improving the structural state and exerting a softening effect on the arable horizon, the use of diatomite and organic fertilizers increases the yield of crops. Doses of diatomite from 2.0 to $8.0 \mathrm{t} / \mathrm{ha}$ increased crop yields by $8.9-18.4 \%$. Against the background of the use of manure at a rate of $48 \mathrm{t} / \mathrm{ha}$, the yield of the first crop had increased. Winter wheat yield had increased by $69.8-86.3 \%$. The yield of the second and third crops had increased from 13.7 to $26.5 \%$.

Keywords: siliceous rock, manure, mineral fertilizers, soil aggregate water stability, bulk density, porosity, yield.

\section{References:}

1. Baybekov, R. F. Agroecological state of soils with prolonged use of fertilizers / R. F. Baybekov. M.: TsINAO, 2003. - $192 \mathrm{p}$.

2. Golovanov, D. L. Silicon - an indispensable macroelement of nutrition of natural and cultural cereals / D. L. Golovanov // Fertilizers and chemical reclamants in agroecosystems. - M.: Publishing House of Moscow State University, 1998. - P. 247-250.

3. Dabakhova, E. V. The study of silicon-containing agents / E. V. Dabakhova, N. V. Zabegalov // Agrochemical Bulletin. - 2011. - No. 2. - P. 28-35.

4. Distanov, U. G. Geological and industrial types of deposits of sedimentary siliceous rocks of the USSR: criteria for their forecast and searches / U. G. Distanov // The origin and practical use of siliceous rocks: Collection of articles of the USSR Academy of Sciences / ed. V. N. Kholodov, I. V. Sednetskiy. Moscow: Nauka, 1987. - P. 157-167.

5. The use of silicon compounds in agriculture / V. M. Dyakov, V. V. Matychenkov, V. A. Chernyshev, Y. M. Ammosova // Actual problems of chemical science and technology and environmental protection. Vol. 7. - Moscow: NIITEKHIM, 1990. - 32 p.

6. Karpukhin, M. Yu. The effectiveness of the use of diatomite as a fertilizer in the cultivation of carrots in the Middle Urals // Agrarian Bulletin of the Urals. - 2014. - No. 1 (119). - P.17-19.

7. Silicon fertilizers as a factor of increasing the drought tolerance of plants / V. V. Matychenkov, A. A. Kosobryukhov, N. I. Shabanova, E. A. Bocharnikova // Agricultural chemistry. - 2007. - No. 5. P.63-67.

8. Kulikova, A. Kh. The effectiveness of the use of diatomite and its mixture with mineral fertilizers in the cultivation of winter and spring wheat / A. Kh. Kulikova, E. A. Yashin, E. V. Danilova // Bulletin of the Ulyanovsk State Agricultural Academy. - 2008. - No. 1 (16). - P. 8-14.

9. Kulikova, A. Kh. Silicon and high-siliceous rocks in the fertilizer system of agricultural crops: monograph / A. Kh. Kulikova. - Ulyanovsk: UGAA by P. A. Stolypin, 2013. - 178 p.

10. Kulikova, A. Kh. Prospects for the use of diatomite in agricultural production / A. Kh. Kulikova // Agroecological problems of agricultural production in conditions of anthropogenic pollution: materials of the All-Russian Scientific and Practical Conference. - Ulyanovsk, 2004. - P. 187-191.

11. Kulikova, A. Kh. The use of biological products and diatomaceous powder in the cultivation of barley / A. Kh. Kulikova, S. A. Nikiforova, E. A. Nikiforov // Fertility. - 2008. - No. 5. - P. 36-37.

12. Loboda, B. P. Diatomites and tripoli as soil improvers and sources of nutrients / B. P. Loboda, N. N. Yakovleva // Fertility. - 2003. - No. 5. - P. 11-14. 
13. Matychenkov, V. V. The role of mobile silicon compounds in plants and the soil-plant system: dissertation abstract for the degree of Doctor of Biological Sciences: 03.00.12, 03.00.27 / Vladimir Viktorovich Matichenkov. - Pushchino, 2008. - 34 p.

14. Sychev, V. G. The current state and dynamics of fertility of arable soils in Russia / V. G. Sychev, M. I. Lunev, A. V. Pavlihina // Fertility. - 2012. - No. 4. - P. 5-7.

15. Yashin, E. A. Efficiency of using diatomite and its mixtures with chicken manure as a fertilizer for crops in leached chernozem of the Middle Volga region: dissertation abstract for the degree of Candidate of Agricultural Sciences: 06.01.04 / Evgeniy Aleksandrovich Yashin. - Saransk, 2004. - 20 p.

16. Barzegar, A. R. The effect of addition of different amounts and types of organic materials on soil physical properties and yield of wheat/A. R. Barzegar, A. Yousefi, A. Daryashenas // Plant Soil. - 2002. - № 247. - P. 295-301.

17. Chang, M. Y. Production of silicon carbide liquid fertilizer by hydrothermal carbonization processes from silicon containing agricultural waste biomass / M. Y. Chang, W. J. Huang // Eng J-Thail. 2016. - № 20. - P. 11-17.

18. The use of silicon-containing agro ores for increasing the productivity of agricultural crops / N. P. Checkaev, I. N. Semov, A. Yu. Kuznetsov, A. N. Arefyev, E. G. Rylyakin // Research Journal of Pharmaceutical, Biological and Chemical Sciences. - 2019. - № 1. - P. 114-117.

19. Diatomite releases silica during spirit filtration / J. Gómez, Gil MLA., N. de la Rosa-Fox, M. Alguacil // Food Chem. - 2014. - № 159. - P. 381-387. 